\title{
Teledermatology versus Face-to-Face Dermatology: An Analysis of Cost-Effectiveness from Eight Studies from Europe and the United States
}

\author{
Remedios López-Liria ${ }^{1}$, María Ángeles Valverde-Martínez ${ }^{1}$, Antonio López-Villegas ${ }^{2, *}$, \\ Rafael Jesús Bautista-Mesa ${ }^{3}$, Francisco Antonio Vega-Ramírez ${ }^{4}$, Salvador Peiró ${ }^{5}$ (i) and Cesar Leal-Costa ${ }^{6}$ (i) \\ 1 Health Research Centre, Department of Nursing, Physiotherapy and Medicine, University of Almería, \\ Carretera del Sacramento s/n, La Cañada de San Urbano, 04120 Almeria, Spain; rll040@ual.es (R.L.-L.); \\ mvm637@ual.es (M.Á.V.-M.) \\ 2 Social Involvement of Critical and Emergency Medicine, CTS-609 Research Group, Poniente Hospital, \\ 04700 El Ejido, Spain \\ 3 Economic-Financial Directorate, Alto Guadalquivir Health Agency, 23740 Andujar, Spain; \\ rafael.bautista.mesa@gmail.com \\ 4 Hum-498 Research Team, University of Almeria, 04120 Almeria, Spain; franavega@hotmail.com \\ 5 Health Services Research Unit, FISABIO-Public Health, 46020 Valencia, Spain; peiro_bor@gva.es \\ 6 Nursing Department, University of Murcia, 30120 El Palmar, Spain; cleal@um.es \\ * Correspondence: antoniolopezvillegas@andaluciajunta.es
}

Citation: López-Liria, R.;

Valverde-Martínez, M.Á.;

López-Villegas, A.; Bautista-Mesa,

R.J.; Vega-Ramírez, F.A.; Peiró, S.;

Leal-Costa, C. Teledermatology

versus Face-to-Face Dermatology: An

Analysis of Cost-Effectiveness from

Eight Studies from Europe and the

United States. Int. J. Environ. Res.

Public Health 2022, 19, 2534. https://

doi.org/10.3390/ijerph19052534

Academic Editor: Paul B. Tchounwou

Received: 25 January 2022

Accepted: 19 February 2022

Published: 22 February 2022

Publisher's Note: MDPI stays neutral with regard to jurisdictional claims in published maps and institutional affiliations.

Copyright: () 2022 by the authors Licensee MDPI, Basel, Switzerland. This article is an open access article distributed under the terms and conditions of the Creative Commons Attribution (CC BY) license (https:/ / creativecommons.org/licenses/by/ $4.0 /)$.

\begin{abstract}
Background: The aim of this systematic review was to compare the cost-effectiveness of two follow-up methods (face-to-face and telemedicine) used in dermatology in the last ten years. (2) Methods: A search for articles that included economic analyses was conducted in August 2021 in the databases PubMed, Medline, Scielo and Scopus using the following keywords: "Cost-Benefit Analysis", "Dermatology", "Telemedicine", "Primary Health Care", as well as other search terms and following the PICOS eligibility criteria. (3) Results: Three clinical trials and five observational studies were analyzed, providing information for approximately 16,539 patients (including four cost-minimization or saving analyses, three cost-effectiveness analyses, and one cost-utility analysis) in Europe and the United States. They describe the follow-up procedures in each of the cases and measure and analyze the direct and indirect costs and effectiveness. All the articles indicate that teledermatology lowers costs and proves satisfactory to both patients and professionals. (4) Conclusions: Although it has been found that follow-up via teledermatology can be more efficient than traditional hospital follow-up, more work is needed to establish evaluation protocols and procedures that measure key variables more equally and demonstrate the quality of the evidence of said studies.
\end{abstract}

Keywords: cost-benefit analysis; follow-up studies; health-related quality of life; pacemakers; teledermatology; telemedicine

\section{Introduction}

Telemedicine is proving to be an efficient tool for improving remote medical assistance [1]. Dermatology is the clinical speciality best suited for telemedicine, owing to the visibility of dermatological conditions [2-4].

The concept of teledermatology (TD) was first introduced in 1995 to offer remote dermatology services [5]. More recently, the arrival of the COVID-19 pandemic changed the scheme of in-person consultation within the healthcare system, except for those cases deemed emergencies [3,5]. Although TD was already in use worldwide, the arrival of COVID-19 and the subsequent confinement period consolidated the application of the tool $[4,6]$. Prior to this time, it had primarily been a resource aimed at rural populations with less convenient accessibility [7]. 
Dermatological conditions are a frequent reason for primary care (PC) visits [8]. In general terms, TD is an easy-access tool for professionals in this field worldwide [6,9]. In some countries, TD service begins with PC physicians/nurses taking a photograph of the lesion in question and attaching it to the patient's electronic medical records, along with a brief clinical description. Subsequently, at the referral hospital, the consultant dermatologists view the electronic medical records, observe the images and recommend a treatment or plan of action. Later, PC physicians evaluate these recommendations and contact the patient to convey the results $[8,10]$.

There are several fields in TD care: synchronous, asynchronous or the combination of both $[2,11]$. Synchronous TD offers immediate diagnosis, as the dermatologist views the photograph of the patient in real time (live). In the asynchronous method, or storage TD, the images of the patients are loaded to a platform using a PC and sent to a dermatologist who later establishes a diagnosis. In clinical practice, the most widely utilized is the asynchronous model [8,12]. Those patients with an inconclusive diagnosis or who require an in-person appointment are contacted more quickly, thereby reducing any waiting lists.

TD offers certain advantages over traditional dermatology consultations. It reduces waiting times and costs, improves access in rural areas and/or for patients who experience difficulties in attending in-person appointments and decreases appointment cancellations and absenteeism. Moreover, TD proves to be a useful diagnostic and follow-up tool, favoring early referral in emergency cases $[11,13,14]$. There are, however, other aspects that adversely affect TD. These include technological barriers (poor internet connection, limited access to platforms, poor image quality) or lack of technological skills among professionals and patients, which could hinder attention to geriatric patients or those with a different language, ultimately resulting in the making of possibly erroneous diagnoses $[14,15]$.

The use of TD is greater in countries in North America and Europe [9]. Spain is one of the leading countries with active TD programs [6]. However, in other countries, such as Argentina, TD is currently in its early stages of development [4]. Approximately $38 \%$ of countries worldwide have integrated TD programs. In Australia, Holland and some parts of the United States, TD represents a key part of the healthcare system [16,17], as many rural areas lack dermatologists, thereby favoring its utilization [17].

It seems that the development and expansion of TD is having a positive influence in terms of cost-effectiveness, a fact supported by the few studies and reviews found of this recent practice $[4,9,18]$. However, there are even fewer investigations that focus on the analysis of the cost-effectiveness of TD compared to traditional consultations. It would be rather interesting to establish a comparative between both treatment methods and extract results that could be extrapolated and applied to improve patient care. Bearing this in mind, the aim of this systematic review is to compare the cost-effectiveness of two follow-up methods (face-to-face and telemedicine) used in dermatology over the last ten years.

\section{Materials and Methods}

In August 2021, a systematic review was conducted following the standards set out in the PRISMA statement for systematic reviews $[19,20]$. Said review was previously registered with the International Prospective Register of systematic reviews (PROSPERO) and was assigned number CRD42021267213. A meta-analysis could not be carried out due to the range of study designs used and inconsistent outcome reporting.

A search was conducted for articles published in the last 10 years in PubMed, Medline, Scielo and Scopus. The target population was users of dermatology services and the material was gathered from the studies present in the databases mentioned, existing gray literature and Web of Science. Additionally, manual searches were undertaken to locate bibliographic references deemed to be of interest - those included in systematic reviews and prior meta-analyses. The inclusion criteria were:

1. Articles containing the MeSH terms: "Cost-Benefit Analysis", "Dermatology", "Telemedicine", "Primary Health Care". Other search terms included: "Cost-Utility Analysis", "Economic Evaluation", and "Cost-Effectiveness Analysis", "Teledermatol- 
ogy", "Skin Disease", “Telehealth", "Remote Consult" (conventional or "face-to-face" or standard or in-person).

2. Clinical trials or observational studies comparing the two follow-up methods (face-toface versus TD).

The exclusion criteria were:

1. Description of a single method for intervention or follow-up, without comparison.

2. Clinical guidelines, systematic reviews and meta-analyses.

The search strategy in the different databases is described in Table 1.

The PICOS eligibility criteria (participants, intervention, comparison intervention, results and study design) were used for article selection: participants would be users of dermatology services. Intervention would involve the application of face-to-face dermatological monitoring follow-up (in-person at a hospital) or remote monitoring follow-up using telemedicine (teledermatology). The results measured were the costs of these followup methods for dermatological conditions, as well as secondary measures, such as the effectiveness or satisfaction of users and professionals. As for the type of study required, investigations had to be observational studies or clinical trials.

Articles should evaluate (main variables): number of visits, economic impact or identification of costs, such as those directly attributable to TD and/or face-to-face dermatology service (including cameras, hardware and staff).

Among the other variables considered were: costs not directly attributable to dermatology service (such as building maintenance, information technology (IT) services, gas, electricity, telephone-internet connections and medical insurance). Also taken into account were costs incurred by patients and society, for example, lost productive time, lost salaries, leisure time lost, time spent traveling to visits and petrol.

Following the application of the search strategy, a total of 71 articles were selected (between 13 and 31 August 2021), which were analyzed by title and abstract.

The extraction and reading of all titles and abstracts of the studies initially selected was carried out independently by two researchers (R.L.-L. and M.Á.V.-M.), who consulted a third individual (A.L.-V.) if there was any disagreement about the inclusion/exclusion of an article.

After an initial screening of the studies considered to be potentially relevant, a full-text critical reading of 27 articles was performed, paying particular attention to the intervention (type of treatment) and cost-benefit evaluation. Finally, it was determined that a total of eight articles met the objective and fulfilled the criteria proposed for this review (Figure 1). A descriptive analysis of the selected results was carried out. Disagreements were resolved through discussion among the reviewers until a consensus was reached.

The quality of the studies was evaluated using the Downs and Black quality assessment method [21]. This method contains 27 items divided into five sections: study quality, external validity, study bias, confounding and selections bias and study power. Scores range from 0 to 28; higher scores indicate a better methodological quality of the study: excellent (26-28), good (20-25), fair (15-19), and poor $(<14)$ This scale has high validity and reliability, ranked as one of the six best quality assessment scales suitable for systematic reviews [22,23]. 
Table 1. Databases and search terms.

Databases and Search Terms

Results Selected Articles

\section{SCOPUS, SCIELO, MEDLINE}

1. "Cos-Benefit Analysis" AND "Dermatology" AND "Telemedicine"

2. "Cost-Utility Analysis" AND "Dermatology" AND "Telemedicine"

3. "Economic Evaluation" AND "Dermatology" AND "Telemedicine"

4. "Cost-Effectiveness Analysis" AND "Dermatology" AND "Telemedicine"

5. "Cost- Benefit Analysis" AND "Dermatology" AND "Primary Health Care"

6. "Teledermatology" AND "Remote Consult * AND "Conventional" OR "Face-to-face" OR "Standard" OR "In-person" AND Cost *

7. “Telederm*" AND “Telemed *" AND “Dermatol *" AND "Skin Disease" AND "Telehealth" AND "Dermatol *" AND "Conventional" OR "Standard" OR "Face-to-face" OR "In-Person" OR "Primary Health Care" OR "Remote Consult*" AND "Cost *" AND "Cost-Benefit Analysis" AND "Cost-Utility Analysis" AND “Economic Evaluation" AND "Cost-Effectiveness Analysis"

1. "Cos-Benefit Analysis" AND “Dermatology" AND “Telemedicine"

\section{PUBMED}

2. "Cost-Utility Analysis" AND "Dermatology" AND "Telemedicine"

3. "Economic Evaluation" AND "Dermatology" AND "Telemedicine"

4. "Cost-Effectiveness Analysis" AND "Dermatology" AND "Telemedicine"

5. "Cost- Benefit Analysis" AND "Dermatology" AND "Primary Health Care"

6. “Teledermatology" AND "Remote Consult * AND "Conventional" OR "Face-to-face" OR "Standard" OR "In-Person" AND "Cost *

7. “Telederm *" AND "Telemed *" AND "Dermatol * AND "Skin Disease" AND “Telehealth" AND "Dermatol *" AND "Conventional" OR "Standard" OR “Face-to-face" OR “In-Person" OR "Primary Health Care" OR "Remote Consult" AND "Cost *" AND "Cost-Benefit Analysis" AND "Cost-Utility Analysis" AND "Economic Evaluation" AND "Cost-Effectiveness Analysis" 


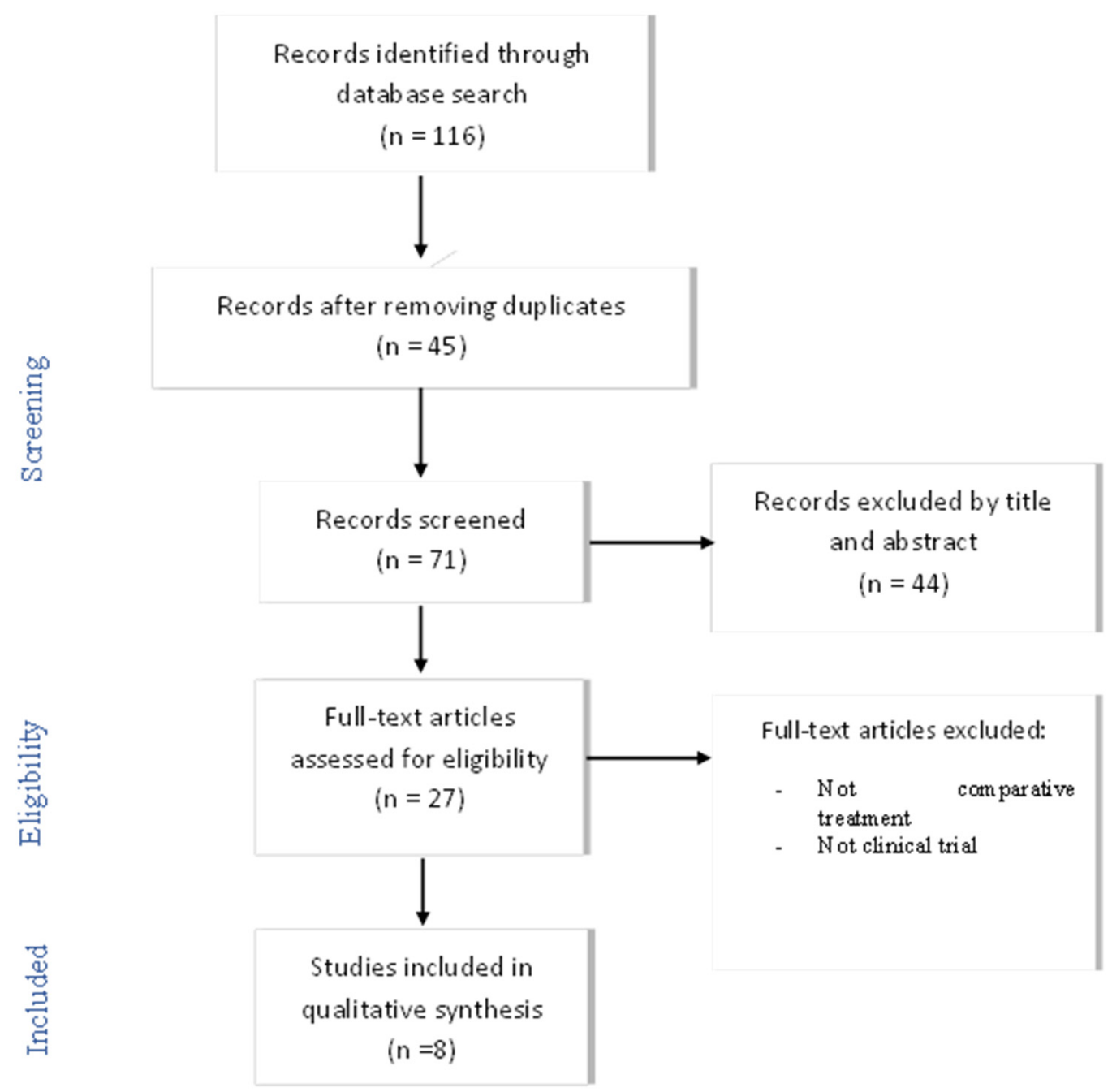

Figure 1. Flowchart of articles selection process. $n=$ number of articles.

\section{Results}

Eight articles were included which provided information on 16,539 patients (including four cost-minimization or saving analyses, three cost-effectiveness analyses and one costutility analysis]. They described how the follow-ups were conducted for each of the methods and contained at least a cost analysis.

The following Table 2 presents a summary of the studies selected, indicating: type of study, country, number of participants, follow-up method in each group, the variables that measured direct and indirect costs, effectiveness and the main results obtained.

The following section presents the content analysis of the information based on the most important variables (Table 3):

\subsection{Description of TD Procedure versus Face-to-face Follow-Up}

Among the various procedures used in dermatology, all the articles use an asynchonous model, in which the images of the patient are uploaded to a platform along with a brief clinical history, after which the dermatologist establishes a diagnosis and treatment plan [24-30].

Patients attend an initial consultation with a PC dermatology doctor [24-29] or nurse [30] who takes the photos of the affected area and uploads them to an online platform which a dermatologist can access remotely. In the study by Parsi [31], the patients themselves take photos of their own skin and upload them to the platform. 
Table 2. Description of the main results in the selected articles.

\begin{tabular}{|c|c|c|c|}
\hline $\begin{array}{l}\text { Author, Year } \\
\text { Country }\end{array}$ & $\begin{array}{c}\text { Type of Study } \\
\text { Participants } \\
\text { Diagnosis }\end{array}$ & $\begin{array}{l}\text { Dermatology } \\
\text { Follow-Up } \\
\text { Method }\end{array}$ & Main Results \\
\hline
\end{tabular}

A retrospective cost-minimization analysis

In TD:

- 1297 patients did not require in-person consultation

- 801 patients required in-person consultation

Zakaria, 2020 [24] In conventional care:

United States

- 646 patients did not require dermatological consultation

- $\quad 1452$ had consultation and follow-up

Diagnosis of benign processes, infections and seborrheic

dermatitis

Inter-level multicentre retrospective study

$n=7030$ patients

- 2629 patients required in-person consultation

- 4349 patients diagnosed with TD

López-Villegas, 2020 [25] 3507 diagnosed and treated by dermatologist using the

Spain

\section{Compared dermatology}

patients within a TD triage system

vs. a conventional dermatology care

model

Asynchronous

st PC consultation + TD

consultation

Follow-up: 6 months

Average cost/patient TD: $\$ 559.84$

Average cost/patient conventional consultation: $\$ 699.96$

TD reduces costs by $\$ 140.12$ ( $\$ 11.01)$ per

patient, representing approximately $\$ 441,378$ per year.

108 required clarification from PC personnel

2 excluded, software error

Teledermatology units compared to conventional monitoring at hospitals Asynchronous

1st PC consultation + TD

consultation

730 received recommendations from PC doctor

Diagnoses: non-benign pathologies (basal-cell carcinoma melanoma,

squamous-cell carcinoma,

other types of skin cancer) and Benign pathologies

(actinic keratosis)

Savings of $61.86 \%$ of hospital visits

There was a cost savings of $31.68 \%$ in the TD group ( $€ 18.59$ TD vs. $€ 27.20 \mathrm{CM}$ ) during the follow-up period. The number of $\mathrm{CM}$ visits to the hospital reduced by $38.14 \%$. From the patients' perspective, the costs were lower, and the cost savings was $73.53 \%$ ( $€ 5.45 \mathrm{TD}$ vs. $€ 20.58 \mathrm{CM}$ ).

TD is an economic solution in comparison with conventional dermatology, both from the perspective of the public healthcare system and the patient, obtaining clear cost savings The results cannot be extrapolated to countries with different healthcare systems 
Table 2. Cont.

\begin{tabular}{|c|c|c|c|}
\hline $\begin{array}{l}\text { Author, Year } \\
\text { Country }\end{array}$ & $\begin{array}{l}\text { Type of Study } \\
\text { Participants } \\
\text { Diagnosis }\end{array}$ & $\begin{array}{l}\text { Dermatology } \\
\text { Follow-Up } \\
\text { Method }\end{array}$ & Main Results \\
\hline $\begin{array}{l}\text { Vidal-Alaball, } 2018 \text { [26] } \\
\text { Spain }\end{array}$ & $\begin{array}{l}\text { Observational Study } \\
n=5606 \text { patients } \\
1104 \text { patients sent to in-person consultation } \\
\text { No specific mention of main diagnoses }\end{array}$ & $\begin{array}{l}\text { A cost-savings analysis comparing } \\
\text { teledermatology with traditional } \\
\text { dermatology consultations } \\
\text { (face-to-face) } \\
\text { Asynchronous } \\
\text { 1st PC consultation + TD } \\
\text { consultation } \\
\text { Follow-up: } 3 \text { months }\end{array}$ & $\begin{array}{l}\text { TD saved } 4502 \text { in-person visits. } \\
\text { The use of TD versus face-to-face } \\
\text { consultations generates savings of } \\
51,164.00 \text { euros/year ( } 11.40 \text { euros / patient) } \\
\text { Societal savings are the most significant } \\
\text { Cannot be extrapolated to countries with } \\
\text { different healthcare systems }\end{array}$ \\
\hline $\begin{array}{l}\text { Yang, } 2018 \text { [27] } \\
\text { United States }\end{array}$ & $\begin{array}{l}\text { A retrospective study of the cases } \\
n=700 \text { patients } \\
189 \text { patients required in-person consultation } \\
23 \text { required urgent care } \\
86 \% \text { of patients were assisted via TD }\end{array}$ & $\begin{array}{l}\text { Analysis compared the cost of each } \\
\text { patient case with use of the TD } \\
\text { consultation model vs. conventional } \\
\text { care } \\
\text { Asynchronous } \\
\text { 1st PC consultation + TD } \\
\text { consultation } \\
\text { Follow-up: } 5 \text { years }\end{array}$ & $\begin{array}{l}\text { Compared with conventional care, TD had an } \\
\text { average expected cost savings of } \$ 10.00 \text { to } \\
\$ 52.65 \text { per TD consultation } \\
\text { Providing access to high-quality care, this } \\
\text { program reduced unnecessary in-person } \\
\text { dermatology clinical visits as well as } \\
\text { urgent care } \\
\text { Significantly reduces the costs of } \\
\text { dermatological care, increases access and } \\
\text { improves patient satisfaction and } \\
\text { clinical results }\end{array}$ \\
\hline $\begin{array}{l}\text { Zarca, } 2018 \text { [28] } \\
\text { France }\end{array}$ & $\begin{array}{l}\text { Retrospective cohort study } \\
n=450 \text { prisoners } \\
82 \%(368 / 450) \text { of the patients with tele-expertise had a } \\
\text { complete treatment plan } \\
\text { The most frequent lesions were acnea and atopic } \\
\text { dermatitis }\end{array}$ & $\begin{array}{l}\text { Evaluate the effectiveness and costs } \\
\text { of tele-expertise in dermatology } \\
\text { Follow-up: } 1 \text { year }\end{array}$ & $\begin{array}{l}\text { For } 368 \text { patients every year, the average cost is } \\
€ 184 \text { for completed treatment plans distributed } \\
\text { as follows: } 34 \% \text { investment, } 66 \% \text { operating } \\
\text { cost ( } 30 \% \text { human resource, } 36 \% \text { software) } \\
\text { Tele-expertise was found to be effective, } \\
\text { increasing the proportion of patients with } \\
\text { completed treatment plans and the overall } \\
\text { satisfaction of physicians, at a cost far lower } \\
\text { than a dermatologist consultation in a hospital }\end{array}$ \\
\hline
\end{tabular}


Table 2. Cont.

\begin{tabular}{|c|c|c|c|}
\hline $\begin{array}{l}\text { Author, Year } \\
\text { Country }\end{array}$ & $\begin{array}{c}\text { Type of Study } \\
\text { Participants } \\
\text { Diagnosis }\end{array}$ & $\begin{array}{l}\text { Dermatology } \\
\text { Follow-Up } \\
\text { Method }\end{array}$ & Main Results \\
\hline $\begin{array}{l}\text { Datta, } 2015 \text { [29] } \\
\text { United States }\end{array}$ & $\begin{array}{l}\text { Randomized clinical trial } \\
\text { Conventional } n=196 \text { patients } \\
\text { TD: } n=195 \text { patients } \\
1 \text { patient excluded, assignment error } \\
\text { Ambulatory skin conditions }\end{array}$ & $\begin{array}{l}\text { To assess the costs and utility of a } \\
\text { store-and-forward teledermatology } \\
\text { referral process compared with } \\
\text { conventional referral process. } \\
\text { Asynchronous } \\
\text { 1st PC consultation PC + TD } \\
\text { consultation } \\
\text { Follow-up: } 9 \text { months }\end{array}$ & $\begin{array}{l}\text { The TD cost per patient was } \$ 30 \text { lower and, } \\
\text { from a societal perspective, saved } \$ 82 \\
\text { The differences in effectiveness for both } \\
\text { groups were not significant } \\
\text { Compared with conventional referrals, } \\
\text { store-and-forward teledermatology referrals } \\
\text { were performed at a comparable cost (VA } \\
\text { perspective) or at a lower cost (societal } \\
\text { perspective) with no evidence of a difference } \\
\text { in utility as measured by the time trade-off } \\
\text { method }\end{array}$ \\
\hline $\begin{array}{l}\text { Os-Medendorp, } 2012 \text { [30] } \\
\text { Netherlands }\end{array}$ & $\begin{array}{l}\text { Randomized controlled study with economic evaluation } \\
n=199 \text { patients with atopic dermatitis } \\
\text { CG: } n=98 \\
\text { IG } n=101\end{array}$ & $\begin{array}{l}\text { Determine the cost-effectiveness of } \\
\text { individualized e-health compared } \\
\text { with usual face-to-face care } \\
\text { Asynchronous } \\
\text { 1st appointment with dermatologist } \\
+ \text { TD } \\
\text { Follow-up: } 3 \text { months and after } 1 \\
\text { year }\end{array}$ & $\begin{array}{l}\text { Both interventions proved effective regarding } \\
\text { quality of life and severity of illness, but there } \\
\text { were no significant differences. } \\
\text { The difference in total costs between the CG } \\
\text { and the IG is } € 594 \text { per patient during the first } \\
\text { year of treatment } \\
\text { IG: average } 3378 € \text { per patient } \\
\text { CG: } 3972 € \text { per patient } \\
\text { It is possible that telemedicine is more } \\
\text { economical because it involves fewer days of } \\
\text { work absenteeism; although the results may } \\
\text { not be consistent due to the heterogeneity of } \\
\text { the interventions } \\
\text { Uncertainty analyses revealed that the } \\
\text { probability of e-health reducing costs was } \\
\text { estimated to be around } 73 \%\end{array}$ \\
\hline
\end{tabular}


Table 2. Cont.

\begin{tabular}{|c|c|c|c|}
\hline $\begin{array}{l}\text { Author, Year } \\
\text { Country }\end{array}$ & $\begin{array}{c}\text { Type of Study } \\
\text { Participants } \\
\text { Diagnosis }\end{array}$ & $\begin{array}{c}\text { Dermatology } \\
\text { Follow-Up } \\
\text { Method }\end{array}$ & Main Results \\
\hline $\begin{array}{l}\text { Parsi, } 2011 \text { [31] } \\
\text { United States }\end{array}$ & $\begin{array}{l}\text { Randomized Controlled Trial } \\
\text { Cost-effectiveness } \\
\text { Analyses } \\
n=64 \text { patients with psoriasis. }\end{array}$ & $\begin{array}{l}\text { Compare cost-effectiveness of } \\
\text { conventional in-office care with a } \\
\text { patient-centered, } \\
\text { online model for follow-up } \\
\text { treatment } \\
\text { Asynchronous. Remote monitoring } \\
\text { by the patient (previous training) } \\
\text { Follow-up: } 24 \text { weeks }\end{array}$ & $\begin{array}{l}\text { Both improved patient quality of life and } \\
\text { proved effective: patients gained } 23.3 \text { weeks of } \\
\text { quality of life with TD and } 24.1 \text { with } \\
\text { in-person care } \\
\text { The online model is equally effective but less } \\
\text { expensive than face-to-face: } \\
\text { The cost of follow-up care with online visits } \\
\text { was } 1.7 \text { times less than the cost of in-person } \\
\text { visits ( } \$ 315 \text { vs. } \$ 576) \text {. TD costs } \$ 261.10 \text { less per } \\
\text { patient. Users also expressed their preference } \\
\text { for TD. TD appears to be an innovative and } \\
\text { profitable healthcare model for follow-up and } \\
\text { treatment of patients with psoriasis }\end{array}$ \\
\hline
\end{tabular}

Table 3. Description of "Cost and Effectiveness" Variables.

\begin{tabular}{|c|c|c|c|c|}
\hline Author, Year & Direct Costs & Indirect Costs & Exclusion of Costs & Effectiveness Variables \\
\hline $\begin{array}{l}\text { Zakaria, } \\
2020[24]\end{array}$ & $\begin{array}{l}\text { Costs associated with } \\
\text { PC, dermatology and TD visits (number of } \\
\text { visits) } \\
\text { Personal costs: salary and time } \\
\text { Technological costs: installation of licensed } \\
\text { software, software support, maintenance } \\
\text { services, equipment and training for } \\
\text { professionals }\end{array}$ & No reference made to indirect costs & $\begin{array}{l}\text { Exclusion of rent costs, clinical } \\
\text { supplies, public services and social } \\
\text { costs }\end{array}$ & $\begin{array}{l}\text { Does not include } \\
\text { effectiveness }\end{array}$ \\
\hline $\begin{array}{l}\text { López-Villegas, } \\
2020 \text { [25] }\end{array}$ & $\begin{array}{l}\text { Costs from PHS perspective: } \\
\text { Number of both conventional and TD visits } \\
\text { PC and hospital costs: labour costs and } \\
\text { specific costs of TD equipment and materials } \\
\text { (Canon EOS camera and dermascopy lens); } \\
\text { every } 5 \text { years }\end{array}$ & $\begin{array}{l}\text { Patient Cost Perspective: } \\
\text { Transport costs, travel time, waiting } \\
\text { time and time of visit }\end{array}$ & $\begin{array}{l}\text { Exclusion of structural costs } \\
\text { (electricity, telecommunications, } \\
\text { construction and maintenance) } \\
\text { Exclusion of number of trips and } \\
\text { wages lost by companions }\end{array}$ & $\begin{array}{l}\text { Effectiveness was not } \\
\text { measured }\end{array}$ \\
\hline
\end{tabular}


Table 3. Cont.

\begin{tabular}{|c|c|c|c|c|}
\hline Author, Year & Direct Costs & Indirect Costs & Exclusion of Costs & Effectiveness Variables \\
\hline $\begin{array}{l}\text { Vidal-Alaball, } \\
2018 \text { [26] }\end{array}$ & $\begin{array}{l}\text { Number of PC, dermatological and TD visits. } \\
\text { Direct costs: cameras, hardware and } \\
\text { personnel } \\
\text { Equipment costs: iPad Air with WIFI and a } \\
\text { mobile phone with } 32 \text { GB; every } 5 \text { years. }\end{array}$ & $\begin{array}{l}\text { Costs included building maintenance, } \\
\text { IT services, gas, electricity, } \\
\text { telephone-internet connections } \\
\text { and medical insurance } \\
\text { Patient costs: Loss of productive time, } \\
\text { salary and transport costs (time and } \\
\text { fuel) }\end{array}$ & $\begin{array}{l}\text { Exclusion of costs incurred by } \\
\text { companions, loss of free time, } \\
\text { technical and maintenance costs, } \\
\text { training costs for professionals and } \\
\text { medical insurance }\end{array}$ & $\begin{array}{l}\text { Effectiveness was not } \\
\text { measured }\end{array}$ \\
\hline Yang, 2018 [27] & $\begin{array}{l}\text { Direct medical } \\
\text { costs of health care: } \\
\text { average cost of an } \\
\text { in-person dermatology visit, an } \\
\text { emergency dermatology visit, and the } \\
\text { dermatologist for a TD visit }\end{array}$ & $\begin{array}{l}\text { Indirect costs } \\
\text { were not included }\end{array}$ & $\begin{array}{l}\text { Separate } \\
\text { costs for medications, patient travel, } \\
\text { laboratory work } \\
\text { and/or imaging or procedures } \\
\text { outside of the visits were not } \\
\text { included in the analysis }\end{array}$ & $\begin{array}{l}\text { PC doctors were asked } \\
\text { about their satisfaction } \\
\text { with using TD }\end{array}$ \\
\hline Zarca, 2018 [28] & $\begin{array}{l}\text { Evaluates image quality but not diagnostic } \\
\text { precision } \\
\text { Costs of transport, facilities and hospitals } \\
\text { Investment costs } \\
\text { Operational costs: } \\
\text { maintenance and human resources }\end{array}$ & $\begin{array}{l}\text { The proportion of patients with a } \\
\text { completed treatment plan for skin } \\
\text { lesions, the proportion of technical } \\
\text { problems, the quality of the pictures, } \\
\text { the investment and operating costs } \\
\text { and the satisfaction of the } \\
\text { professionals } \\
\text { Average cost of a complete treatment } \\
\text { plan: investment costs + operational } \\
\text { costs }\end{array}$ & $\begin{array}{l}\text { They could not evaluate the } \\
\text { diagnostic accuracy of telemedicine; } \\
\text { the causes of "failed upload, } \\
\text { unanswered requests } \\
\text { and unsatisfactory requests"; unable } \\
\text { to measure patient satisfaction }\end{array}$ & $\begin{array}{l}\text { Satisfaction survey for } \\
\text { doctors. }\end{array}$ \\
\hline Datta, 2015 [29] & $\begin{array}{l}\text { The cost elements from the VA perspective } \\
\text { included: TD intervention or referral; referral } \\
\text { and follow-up visits to the dermatology clinic; } \\
\text { dermatological medications prescribed; travel } \\
\text { cost reimbursement to patients paid by the } \\
\text { VA; and dermatology-related hospitalizations }\end{array}$ & $\begin{array}{l}\text { Dermatological care } \\
\text { sought outside of the VA system; } \\
\text { travel costs in seeking health care if } \\
\text { not reimbursed by the VA; and work } \\
\text { or productivity loss owing to the } \\
\text { patient }\end{array}$ & $\begin{array}{l}\text { They did not include the equipment } \\
\text { cost in TD }\end{array}$ & $\begin{array}{l}\text { Time trade-off determines } \\
\text { the quality of life one } \\
\text { experiences in a given } \\
\text { state of health by } \\
\text { assessing the equivalence } \\
\text { point between living a } \\
\text { longer life with the given } \\
\text { medical condition vs. a } \\
\text { shorter life in perfect } \\
\text { health }\end{array}$ \\
\hline
\end{tabular}


Table 3. Cont.

\begin{tabular}{|c|c|c|c|c|}
\hline Author, Year & Direct Costs & Indirect Costs & Exclusion of Costs & Effectiveness Variables \\
\hline $\begin{array}{l}\text { Os-Medendorp, } \\
2012 \text { [30] }\end{array}$ & $\begin{array}{l}\text { Costs of primary care, e-health service and } \\
\text { outpatient clinics } \\
\text { Care at the dermatology department } \\
\text { Telephone consultation with a dermatologist } \\
\text { Combined visit to dermatology nurse and } \\
\text { dermatologist } \\
\text { Day of hospitalization } \\
\text { Number of e-consultations with dermatology } \\
\text { nurse } \\
\text { Care at other hospital departments } \\
\text { Care by the general practitioner }\end{array}$ & $\begin{array}{l}\text { Two modules online of the 'Health } \\
\text { and Labour Questionnaire' } \\
\text { Written diary to gather data } \\
\text { regarding days on leave from work } \\
\text { Visits with transportation and } \\
\text { parking costs to a medical specialist } \\
\text { or nurse in a hospital; a general } \\
\text { practitioner; days of work } \\
\text { absenteeism; hours with loss of } \\
\text { productivity during work; hours with } \\
\text { loss of productivity in unpaid work }\end{array}$ & Equipment costs not included & $\begin{array}{l}\text { Quality of life, itch } \\
\text { intensity and severity of } \\
\text { atopic dermatitis } \\
\text { *DLQI } \\
\text { *IDQOL } \\
\text { *VAS } \\
\text { Two parts of the online } \\
\text { questionnaire "Impact of } \\
\text { Chronic Skin Disease on } \\
\text { Daily Life" (shortened } \\
\text { version) }\end{array}$ \\
\hline Parsi, $2011[31]$ & $\begin{array}{l}\text { Social perspective: } \\
\text { Online costs: } \\
\text { Medical: clinic and facility fees, morbidity } \\
\text { and mortality } \\
\text { Non-medical: loss of productivity, cost of } \\
\text { patient's time, equipment (camera, computer) } \\
\text { In-office costs: } \\
\text { Medical: clinic and facility fees, morbidity } \\
\text { and mortality } \\
\text { Non-medical: loss of productivity, cost of } \\
\text { patient's time (including travel costs) }\end{array}$ & $\begin{array}{l}\text { Costs of patient's time: patient } \\
\text { wages/minute, duration of visit, cost } \\
\text { of patient's time/visit }\end{array}$ & Not included & 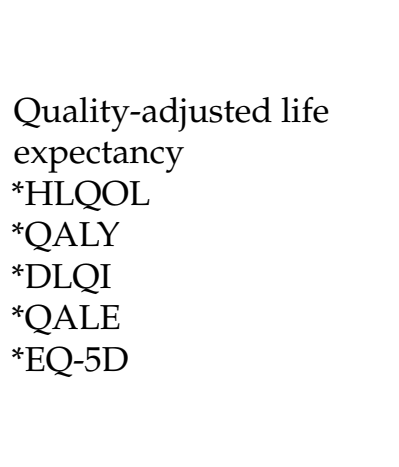 \\
\hline
\end{tabular}

of life measured by the current health condition of an individual; QALY = Quality-adjusted life years; QALE = Quality-adjusted life expectancy; EQ-5D = European Quality of Life 5-Dimension Questionnaire. 
For example, in the study by Zakaria et al. [24], the referring clinicians are required to upload patient photographs and a brief history through a web-based telemedicine platform. An attending dermatologist reviews TD cases weekly and determines which patients require an in-person appointment at the dermatology clinic. When a dermatology visit is not recommended, the referring clinician is expected to coordinate the dermatologist's recommended workup and treatment plan.

Os-Medendorp [30] describes an e-health portal for patients consisting of e-consultation, a patient-tailored website, monitoring and self-management training.

Some studies consider the preliminary training of the doctor or patient in taking photographs correctly [24,28,30]. Only in the studies by Os-Medendorp et al. [30] and Parsi et al. [31] do patients receive advice on self-care in addition to general information and individualized guidance on their dermatological condition.

In the article by López-Villegas et al. [25], photographs are taken with a dermascope. All others use images taken with a mobile phone or similar devices [24,26-31].

The face-to-face or conventional dermatological practice used in all the studies consists of an in-person consultation at a hospital [24-31].

Follow-up periods vary between three [26], six [24] and nine [29] months and one [25,28,30] and five years [27].

\subsection{Variables That Measure Direct and Indirect Costs}

The types of economic analysis and economic perspectives vary greatly among these studies.

In general, nearly all the articles include the labour costs of the heathcare professionals and the patients [24-26,29-31]. However, in the case of Zarca [28], the salary of patients is not included, as the patients being studied were inmates. The article by Yang [27] includes the costs of PC, dermatology and TD consultations by establishing estimations (minimum, mean and maximum).

Zakaria [24], López-Villegas [25] and Vidal-Alaball [26], assess personal costs (salary and time), technological costs, as well as the number of PC, dermatological and TD consultations. The three studies exclude maintenance costs and those incurred by patients' companions.

In order to determine the number of face-to-face consultations saved in Spain, LópezVillegas [25] and Vidal-Alaball [26] utilize the following equation:

\section{$\mathrm{N}^{\mathrm{o}}$ TD consultations $-\mathrm{N}^{\mathrm{o}}$ consultations requested following}

Zakaria [24] utilizes a decision tree model to analyze the difference in costs for patient management and real costs instead of estimations.

López-Villegas [25] and Vidal-Alaball [26] assess, from the patients' perspective, travel time (according to distance obtained using Google Maps) and the cost of gasoline $(\mathrm{km} / \mathrm{h}$, established by the Spanish Ministry of Finance). Both studies assume that the patients use their personal means of transport. They also consider waiting time, consultation time and legal average salary per hour.

\subsection{Variables That Measure the Effectiveness of TD versus Face-to-Face Follow-Up}

A medical treatment is generally considered to be cost-effective based on the following conditions: it provides an added health benefit at an equal or lower cost than the opposing treatment; it provides an added health benefit that is worth an additional cost; or it provides a lesser health benefit but comes with cost savings that are more valuable than the health benefit lost [31].

A variety of questionnaires were used to measure effectiveness. On the one hand, in the study by Yang et al. [27], the PC doctor has to respond to the question: "Without the TD service, how would this patient have otherwise received care for this condition?" with these options: (1)"I would take care of the issue myself", (2) "I would refer the patient for an inperson dermatologist visit" or (3) "I would refer the patient to urgent care or an emergency room (ER)". Based on their answers, $60 \%$ of cases would be handled by the PC doctor, 
$35.6 \%$ would be referred for a dermatologist visit and $4.4 . \%$ to an emergency room. On the other hand, Zarca [28], uses the MAST Model (Model for Assessment of Telemedicine) to conduct a multidimensional evaluation in which PC doctors and dermatologists had to respond to a 6-item survey.

To measure quality of life, Os-Medendorp [30] and Parsi [31] utilize the Dermatology Life Quality Index (DLQI). Os-Medendorp [30] also uses the Infants' Dermatititis Quality of Life Index (IDQIL), while Parsi [31], applies the "European Quality of Life Survey5 Dimensions", along with Quality-Adjusted Life Expectancy (QALE) and Quality-Adjusted Life Year (QALY).

As for the study by Datta et al. [29], quality of life is determined according to the patient's health condition: living longer with a dermatological condition versus living for a shorter time with perfect health.

For the purpose of gathering information on the status of skin, the "Impact of Chronic Skin Disease on Daily Life" questionnaire was used, along with the VAS scale to measure itch intensity and the "Health and Labour Questionnaire" to determine the loss of productivity [30].

\subsection{Comparison of Cost-Effectiveness in Each Method of Follow-Up}

In the study by Parsi [31], TD proves to have the greatest savings in relation to inperson consultation, which is in keeping with that of Zakaria [24], in which TD obtains a mean savings of $\$ 110.12$ per patient. The cost reduction, albeit lower, is also found to be evident in the studies by Vidal-Alaball [26] and Datta [29].

The study by López-Villegas [25] indicates that TD effectively saves more than 50\% of visits with respect to face-to-face follow-up within the public healthcare system. In the article by Vidal-Alaball [26], only a small percentage of participants required an in-person consultation.

Yang [27] finds that in-person consultations were reduced to 14\%, representing significant cost savings. Zarca [28] also identifies an evident cost reduction, yet one that depends on the number of patients treated.

Once again referencing the study by Datta [29], it does not show statistically significant differences between both methods in terms of effectiveness.

Similary, Os-Medendorp [30] fails to indentify any significant differences in terms of the quality of life of patients with atopic dermatitis, finding TD to be as effective as in-person consultation. However, the article by Parsi [31] cites the existence of a slightly higher improvement in the quality of life of patients with the in-person method, yet, in terms of preference, the patients support online treatment.

Regarding satisfaction among doctors, Zarca [28] finds that doctors display greater satisfaction with TD.

\subsection{Level of Evidence and Quality of Articles Included}

Table 4 shows the score of each item of the Downs and Black scale [21]. The mean score of the studies included was 22.12 (range: 17-26), considering that the highest possible score was 28 points. Based on the cut-off points suggested for categorizing studies according to their quality, one article was evaluated as "fair" (15-19 points) and seven were classified as "good" (20-25 points). 
Table 4. Methodological Quality of Studies.

\begin{tabular}{|c|c|c|c|c|c|c|c|c|c|c|c|c|c|c|c|c|c|c|c|c|c|c|c|c|c|c|c|c|c|}
\hline \multirow[b]{2}{*}{ Author (Year) } & \multirow[b]{2}{*}{1} & \multirow[b]{2}{*}{2} & \multirow[b]{2}{*}{3} & \multicolumn{4}{|c|}{ Study Quality } & \multirow[b]{2}{*}{8} & \multirow[b]{2}{*}{9} & \multirow[b]{2}{*}{10} & \multicolumn{3}{|c|}{$\begin{array}{l}\text { External } \\
\text { Validity }\end{array}$} & \multicolumn{6}{|c|}{ Study Bias } & \multicolumn{7}{|c|}{$\begin{array}{c}\text { Confounding and Selection } \\
\text { Bias }\end{array}$} & \multicolumn{2}{|c|}{$\begin{array}{l}\text { Study } \\
\text { Power }\end{array}$} & \multirow[b]{2}{*}{ Quality } \\
\hline & & & & 4 & 5 & 6 & 7 & & & & 11 & 12 & 13 & 14 & 15 & 16 & 17 & 18 & 19 & 20 & 21 & 22 & 23 & 24 & 25 & 26 & 27 & Total & \\
\hline $\begin{array}{l}\text { Zakaria, } \\
2020[24]\end{array}$ & 1 & 1 & 1 & 1 & 0 & 1 & 1 & 1 & 1 & 1 & 1 & 1 & 1 & 1 & 1 & 1 & 1 & 1 & 1 & 1 & 1 & 1 & 0 & 0 & 0 & 1 & 1 & 23 & Good \\
\hline $\begin{array}{c}\text { López-Villegas, } \\
2020 \text { [25] }\end{array}$ & 1 & 1 & 0 & 1 & 0 & 1 & 0 & 1 & 1 & 1 & 1 & 1 & 1 & 1 & 1 & 0 & 1 & 1 & 1 & 1 & 1 & 1 & 0 & 0 & 0 & 1 & 1 & 21 & Good \\
\hline Yang, 2018 [27] & 1 & 1 & 1 & 1 & 0 & 1 & 1 & 1 & 1 & 1 & 1 & 1 & 1 & 1 & 1 & 0 & 1 & 1 & 1 & 1 & 1 & 1 & 0 & 0 & 0 & 1 & 1 & 22 & Good \\
\hline Zarca, 2018 [28] & 1 & 1 & 1 & 1 & 0 & 1 & 1 & 1 & 1 & 0 & 1 & 1 & 1 & 1 & 1 & 1 & 1 & 1 & 1 & 1 & 1 & 1 & 0 & 0 & 0 & 1 & 0 & 21 & Good \\
\hline Datta, 2015 [29] & 1 & 1 & 1 & 1 & 0 & 1 & 1 & 1 & 1 & 1 & 1 & 1 & 1 & 1 & 1 & 1 & 1 & 1 & 1 & 1 & 1 & 1 & 1 & 1 & 0 & 1 & 1 & 25 & Good \\
\hline $\begin{array}{l}\text { Os-Medendorp, } \\
2012 \text { [30] }\end{array}$ & 1 & 1 & 1 & 1 & 0 & 1 & 1 & 1 & 1 & 1 & 1 & 1 & 1 & 1 & 1 & 1 & 1 & 1 & 1 & 1 & 1 & 1 & 1 & 1 & 0 & 1 & 1 & 25 & Good \\
\hline
\end{tabular}




\section{Discussion}

This systematic review has described studies that compare an online model (telemedicine) with in-office care in dermatology services. Although both models can be considered highly cost-effective, herein, it has been found that teledermatology reduces costs and is satisfactory to both patients and professionals. Reviews, such as those by Barbieri et al. [32], agree that TD has the potential to provide access to suitable, quality care.

Nonetheless, the implementation of TD requires either investments or improvements in healthcare infrastructures and training for professionals, as well as for patients as relates to prevention [18,33]. From the legislative and ethical point of view, TD is considered to be a care method that should respect patient autonomy. According to European legislation, the informed consent of the patient is only necessary in cases where the images taken reveal the identity of the subject and/or are used for teaching or scientific purposes [10].

Zakaria [24] demonstrated that TD favours the remote classification and treatment of patients with dermatological conditions by means of implementing a triage system, which in turn contributes to a reduction of costs. The study by Barbieri et al. [32] also suggests that TD is effective for classification in dermatological consultations and could increase their efficiency.

Several economic analyses have been performed on traditional TD models; however, most are cost-minimization studies and do not regularly use validated clinical outcomes or standardized cost-effectiveness measures [31,34].

It would be interesting to promote the use of dermascopes to take photographs of patients, as used in the study by López-Villegas [25]. Ferrandiz [35] considers that images taken with a dermascope significantly improve diagnoses when compared to other clinical images. This study highlights the importance of a strong interconnection between PC and specialised care (hospital).

The pandemic and the situation caused by COVID-19 have consolidated the use of $\mathrm{TD}$, with no need to interrupt treatments. What is more, these events favored access to specialized care for individuals who, due to specific circumstances, are unable to attend in person [28] or who live in areas that are distant or difficult to reach [36]. Several studies promote the use of TD in rural or isolated areas, such as Cutler et al. [37], for Haiti; Byamba et al. [1], for Mongolia, one of the least densely populated countries worldwide; and Tran et al. [38], for Cairo, Egypt. Similarly, the review by Kozera et al. [39] supports the use of $\mathrm{TD}$ as a valuable service that allows patients in these rural areas to access care.

A systematic review of cost-effectiveness of store-and-forward TD in 2016 [40] suggests that TD can be cost-effective when used as a triage mechanism to reduce face-to-face appointment requirements, although evidence was sparse. It suggests that further economic research is required for TD, which uses dermoscopes in combination with smartphone applications, as well as regarding the possibility and consequences of patients self-capturing and transmitting images.

In the present systematic review, all the studies utilized the method of saving and forwarding images [24-31]. Hadeler et al. [41] states that this type of method is highly satisfactory for the patient, albeit some either declare feeling embarrassed by having photographs taken of their skin or express rejection due to social or religious issues.

All the studies analysed in our revision included pathologies that could be followedup by TD. Some of them did not specify the dermatological condition $[26,27,29]$. The rest of the articles included diverse diseases: benign growths [24,25], infection and eczematous dermatitis [24], acnea [28], atopic dermatitis [30], psoriasis [31] or non-benign pathologies (various types of cancer of the skin) [25]. Only one study [25] refers to the costeffectiveness TD in terms of skin cancer follow-up, although a face-to-face consultation was sometimes necessary.

It would also be necessary to discuss the cost-effectiveness of TD in terms of skin cancer follow-up comparing clinical trials, as during the COVID-19 pandemic this topic or the lack of this follow-up has been of great importance. We have found a study that 
analyzed the potential benefits gained from the addition of dermoscopic images to an internet-based skin cancer screening system [35]. In this trial, teledermoscopy has rendered high sensitivity and specificity to assist the dermatologist in making referral decisions, consequently improving the proportion of correct decisions where the relevant lesions were skin cancer (melanoma), premalignant lesions (actinic keratosis) or lesions suitable for follow-up (atypical nevus or others) [35].

Finally, all the articles in this review state that both treatment methods are effective [24-31]. All the studies found improvements in quality of life with both online and in-office patients. Studies, such as those by Vyas et al. [42], continue their commitment to TD as being a safe tool with comparable or superior effectiveness to traditional consultation, as well as favoring interprofessional collaboration in time and space. This method eliminates a large number of unnecessary referrals and could be utilized as an education tool for patients.

The limitations of this review resemble those found in the cost-effectiveness studies. They are related to the variability of the direct and indirect costs included or excluded and the sample of patients. It is necessary that the patients have similar characteristics and the sample number not be large so as to obtain more evident and reliable results that can be extrapolated to the rest of the population. In addition to the variety of methods used to evaluate costs, QALY and satisfaction have also been measured differently, which could lead to different results and interpretations. Finally, the protocols or method of treatment and the results obtained in each of the studies are quite heterogeneous when compared.

This present study carries implications for clinical practice, supporting the development and expansion of healthcare policies regarding telemedicine services in dermatology, and the results could be extrapolated to other healthcare services, such as online models focused on the patient [31].

Current clinical practice shows that chronic dermatological conditions often require regular dermatological visits and are generally associated with high costs for medical care systems [31]. The TD model represents an innovative and profitable method that provides follow-up care to patients when applied properly with relatively low-risk conditions [32].

This work is intended to be a tool to promote the creation of TD protocols that favor diagnoses and optimal treatments, ultimately reducing both societal and economic costs and providing dermatological care in our society that is more accessible and of higher quality [36].

\section{Conclusions}

The studies included in this investigation consider that follow-up via teledermatology can be more cost-effective than face-to-face follow up.

Nevertheless, teledermatology can vary from one country to another, according to the healthcare system in the studies analyzed. Therefore, more work remains to be done for the purpose of establishing cost-effectiveness evaluation protocols that measure the main variables more heterogeneously and with larger samples of participants, making it possible to conduct analyses and thus demonstrate the quality of the evidence produced by rigorous systematic reviews.

Author Contributions: All authors contributed to the conception of the study and participated in critically appraising and revising the intellectual content of the manuscript. R.L.-L., M.Á.V.-M., A.L.-V. and F.A.V.-R. participated in the acquisition of data. R.J.B.-M.; S.P. and C.L.-C. were responsible for data analysis. M.Á.V.-M. prepared the manuscript draft. All authors have read and agreed to the published version of the manuscript.

Funding: This study has been funded by the Consejería de Salud y Familias of the Junta de Andalucía through the project No. AP-0011-2020C1-F2 AJ-1, belonging to the Call "Research and Innovation Projects in the field of Primary Care and Regional Hospitals and High Resolution Hospital Centers of the Andalusian Public Health System", 2020.

Institutional Review Board Statement: Not applicable.

Informed Consent Statement: Not applicable. 
Data Availability Statement: The datasets used and/or analyzed during the current study are available from the corresponding author upon reasonable request.

Conflicts of Interest: The authors declare no conflict of interest.

\section{References}

1. Byamba, K.; Syed-Abdul, S.; Garcia-Romero, M.T.; Huang, C.-W.; Nergyi, S.; Nyamdorj, A.; Nguyen, P.-A.; Iqbal, U.; Paik, K.; Celi, L.; et al. Mobile teledermatology for a prompter and more efficient dermatological care in rural Mongolia. Br. J. Dermatol. 2014, 173, 265-267. [CrossRef]

2. Andrees, V.; Klein, T.; Augustin, M.; Otten, M. Live interactive teledermatology compared to in-person care-A systematic review. J. Eur. Acad. Dermatol. Venereol. 2019, 34, 733-745. [CrossRef] [PubMed]

3. Lee, J.J.; English, J.C. Teledermatology: A Review and Update. Am. J. Clin. Dermatol. 2017, 19, 253-260. [CrossRef] [PubMed]

4. Alonso, C.; Salerni, G.; Fernández-Bussy, R. Teledermatología: Aplicaciones actuales y futuras. Dermatol. Argent. 2017, 23, 29-33.

5. Kumar, S.; Bishnoi, A.; Vinay, K. Changing paradigms of dermatology practice in developing nations in the shadow of COVID -19: Lessons learnt from the pandemic. Dermatol. Ther. 2020, 33, e13472. [CrossRef] [PubMed]

6. Pasquali, P.; Romero-Aguilera, G.; Moreno-Ramírez, D. Teledermatología en tiempos de pandemia: El antes, el durante y el después. Dermatol. Práctica 2020, 112, 324-329. [CrossRef]

7. Pearlman, R.L.; Le, P.B.; Brodell, R.T.; Nahar, V.K. Evaluation of patient attitudes towards the technical experience of synchronous teledermatology in the era of COVID-19. Arch. Dermatol. Res. 2021, 313, 769-772. [CrossRef] [PubMed]

8. Ayen-Rodríguez, A.; Llamas-Molina, J.M.; Cabrerizo-Carvajal, A.M.; Leon-López, F.J.; Ruiz-Villaverde, R. Teledermatología en el Área Sanitaria Centro Oeste de Granada desde atención primaria a especializada. Semergen 2021, 4, 224-229. [CrossRef] [PubMed]

9. Coustasse, A.; Sarkar, R.; Abodunde, B.; Metzger, B.J.; Slater, C.M. Use of Teledermatology to Improve Dermatological Access in Rural Areas. Telemed. E-Health 2019, 25, 1022-1032. [CrossRef] [PubMed]

10. Trettel, A.; Eissing, L.; Augustin, M. Telemedicine in dermatology: Findings and experiences worldwide-A systematic literature review. J. Eur. Acad. Dermatol. Venereol. 2017, 32, 215-224. [CrossRef] [PubMed]

11. Maddukuri, S.; Patel, J.; Lipoff, J.B. Teledermatology Addressing Disparities in Health Care Access: A Review. Curr. Dermatol. Rep. 2021, 10, 40-47. [CrossRef] [PubMed]

12. Stadler, P.; Senner, S.; Frey, S.; Clanner-Engelshofen, B.M.; Frommherz, L.H.; French, L.E.; Reinholz, M. Teledermatology in times of COVID-19. J. Dermatol. 2021, 48, 620-624. [CrossRef] [PubMed]

13. McKoy, K.; Halpern, S.; Mutyambizi, K. International Teledermatology Review. Curr. Dermatol. Rep. 2021, 10, 55-66. [CrossRef] [PubMed]

14. Kaunitz, G.; Yin, L.; Nagler, A.R.; Sicco, K.L.; Kim, R.H. Assessing Patient Satisfaction with Live-Interactive Teledermatology Visits During the COVID-19 Pandemic: A Survey Study. Telemed. E-Health 2021. [CrossRef] [PubMed]

15. Edwards, H.A.; Shen, X.; Soyer, H.P. Teledermatology Adaptations in the COVID-19 Era. Front. Med. 2021, 8, 675383. [CrossRef] [PubMed]

16. Schuster, B.; Ziehfreund, S.; Tizek, L.; Krause, J.; Biedermann, T.; Zink, A. Wie offen ist die bayerische Bevölkerung für Teledermatologie? Eine Querschnittsstudie in ländlichen und städtischen Regionen Bayerns. Das Gesundh. 2019, 83, 53-58. [CrossRef] [PubMed]

17. Rustad, A.M.; Lio, P.A. Pandemic Pressure: Teledermatology and Health Care Disparities. J. Patient Exp. 2021, 8. [CrossRef]

18. Arias, P.G.; Arenas, E.A.; Blanco, M.A.; Sánchez, J.R.; Gutiérrez, M.G.; García-Nieto, A.V. Aspectos medicolegales de la práctica de la teledermatología en España. Actas Dermosifiliogr. 2020, 112, 127-133. [CrossRef] [PubMed]

19. Urrutia, G.; Bonfill, X. PRISMA declaration: A proposal to improve the publication of systematic reviews and meta-analyses. Med. Clín. 2010, 135, 507-511. [CrossRef]

20. Hutton, B.; Catalá-López, F.; Moher, D. La extensión de la declaración PRISMA para revisiones sistemáticas que incorporan metaanálisis en red: PRISMA-NMA. Med. Clin. 2016, 147, 262-266. [CrossRef] [PubMed]

21. Downs, S.H.; Black, N. The feasibility of creating a checklist for the assessment of the methodological quality both of randomised and non-randomised studies of health care interventions. J. Epidemiol. Community Health 1998, 52, 377-384. [CrossRef]

22. Deeks, J.J.; Dinnes, J.; D’Amico, R.; Sowden, A.J.; Sakarovitch, C.; Song, F.; Petticrew, M.; Altman, D.G.; International Stroke Trial Collaborative Group; European Carotid Surgery Trial Collaborative Group. Evaluating nonrandomized intervention studies. Health Technol. Assess 2003, 7, 1-173. [CrossRef]

23. Saunders, L.D.; Soomro, G.M.; Buckingham, J.; Jamtvedt, G.; Raina, P. Assessing the Methodological Quality of Nonrandomized Intervention Studies. West. J. Nurs. Res. 2003, 25, 223-237. [CrossRef] [PubMed]

24. Zakaria, A.; Miclau, T.A.; Maurer, T.; Leslie, K.S.; Amerson, E. Cost Minimization Analysis of a Teledermatology Triage System in a Managed Care Setting. JAMA Dermatol. 2021, 157, 52-58. [CrossRef]

25. Lopez-Villegas, A.; Bautista-Mesa, R.J.; Baena-Lopez, M.A.; Alvarez-Moreno, M.L.; Montoro-Robles, J.E.; Vega-Ramirez, F.A.; Ordoñez-Naranjo, I.; Hernandez-Montoya, C.J.; Leal-Costa, C.; Peiró, S. Economic impact and cost savings of teledermatology units compared to conventional monitoring at hospitals in southern Spain. J. Telemed. Telecare 2020. [CrossRef] 
26. Vidal-Alaball, J.; Garcia-Domingo, J.L.; Cuyàs, F.G.; Peña, J.M.; Flores-Mateo, G.; Rosanas, J.D.; Valmaña, G.S. A cost savings analysis of asynchronous teledermatology compared to face-to-face dermatology in Catalonia. BMC Heal. Serv. Res. 2018, 18, 650. [CrossRef]

27. Yang, X.; Barbieri, J.S.; Kovarik, C.L. Cost analysis of a store-and-forward teledermatology consult system in Philadelphia. J. Am. Acad. Dermatol. 2018, 81, 758-764. [CrossRef]

28. Zarca, K.; Charrier, N.; Mahé, E.; Guibal, F.; Carton, B.; Moreau, F.; Durand-Zaleski, I. Tele-expertise for diagnosis of skin lesions is cost-effective in a prison setting: A retrospective cohort study of 450 patients. PLoS ONE 2018, 13, e0204545. [CrossRef] [PubMed]

29. Datta, S.K.; Warshaw, E.M.; Edison, K.; Kapur, K.; Thottapurathu, L.; Moritz, T.E.; Reda, D.J.; Whited, J.D. Cost and Utility Analysis of a Store-and-Forward Teledermatology Referral System. JAMA Dermatol. 2015, 151, 1323-1329. [CrossRef]

30. Os-Medendorp, H.; Koffijberg, H.; Kok, P.C.M.E.; Zalm, A.; Bruin-Weller, M.S.; Pasmans, S.G.M.A.; Ros, W.J.G.; Thio, H.B.; Knol, M.J.; Bruijnzeel-Koomen, C.A.F.M. E-health in caring for patients with atopic dermatitis: A randomized controlled costeffectiveness study of internet-guided monitoring and online self-management training. Br. J. Dermatol. 2012, 166, 1060-1068. [CrossRef] [PubMed]

31. Parsi, K.; Chambers, C.J.; Armstrong, A.W. Cost-effectiveness analysis of a patient-centered care model for management of psoriasis. J. Am. Acad. Dermatol. 2012, 66, 563-570. [CrossRef]

32. Barbieri, J.S.; Kovarik, C.L. Inpatient and Tertiary Consultations in Teledermatology. Curr. Dermatol. Rep. 2016, 5, 83-89. [CrossRef]

33. Tognetti, L.; Fiorani, D.; Russo, F.; Lazzeri, L.; Trovato, E.; Flori, M.L.; Moscarella, E.; Cinotti, E.; Rubegni, P. Teledermatology in 2020: Past, present and future per-spectives. Ital. J. Dermatol. Venerol. 2021, 156, 198-212. [CrossRef]

34. Barbieri, J.S.; Nelson, C.A.; James, W.D.; Margolis, D.J.; Littman-Quinn, R.; Kovarik, C.L.; Rosenbach, M. The Reliability of Teledermatology to Triage Inpatient Dermatology Consultations. JAMA Dermatol. 2014, 150, 419. [CrossRef]

35. Ferrándiz, L.; Ojeda-Vila, T.; Corrales, A.; Martín-Gutiérrez, F.J.; Ruíz-De-Casas, A.; Galdeano, R.; Álvarez-Torralba, I.; SánchezIbáñez, F.; Domínguez-Toro, J.M.; Encina, F.; et al. Internet-based skin cancer screening using clinical images alone or in conjunction with dermoscopic images: A randomized teledermoscopy trial. J. Am. Acad. Dermatol. 2017, 76, 676-682. [CrossRef]

36. Nelson, C.A.; Takeshita, J.; Wanat, K.A.; Bream, K.; Holmes, J.H.; Koenig, H.C.; Roth, R.R.; Vuppalapati, A.; James, W.D.; Kovarik, C.L. Impact of store-and-forward (SAF) teledermatology on outpatient dermatologic care: A prospective study in an underserved urban primary care setting. J. Am. Acad. Dermatol. 2016, 74, 484-490.e1. [CrossRef]

37. Cutler, L.; Ross, K.; Withers, M.; Chiu, M.; Cutler, D. Teledermatology: Meeting the Need for Specialized Care in Rural Haiti. J. Health Care Poor Underserved 2019, 30, 1394-1406. [CrossRef]

38. Tran, K.; Ayad, M.; Weinberg, J.; Cherng, A.; Chowdhury, M.; Monir, S.; El Hariri, M.; Kovarik, C. Mobile teledermatology in the developing world: Implications of a feasibility study on 30 Egyptian patients with common skin diseases. J. Am. Acad. Dermatol. 2011, 64, 302-309. [CrossRef]

39. Kozera, E.K.; Yang, A.; Murrell, D.F. Patient and practitioner satisfaction with tele-dermatology including Australia's indigenous population: A systematic review of the literature. Int. J. Women's Dermatol. 2016, 2, 70-73. [CrossRef]

40. Snoswell, C.; Finnane, A.; Janda, M.; Soyer, H.P.; Whitty, J.A. Cost-effectiveness of Store-and-Forward Teledermatology. JAMA Dermatol. 2016, 152, 702-708. [CrossRef]

41. Hadeler, E.; Gitlow, H.; Nouri, K. Definitions, survey methods, and findings of patient satisfaction studies in teledermatology: A systematic review. Arch. Dermatol. Res. 2020, 313, 205-215. [CrossRef] [PubMed]

42. Vyas, K.S.; Hambrick, H.R.; Shakir, A.; Morrison, S.; Tran, D.C.; Pearson, K.; Vasconez, H.C.; Mardini, S.; Gosman, A.A.; Dobke, M.; et al. A Systematic Review of the Use of Telemedicine in Plastic and Reconstructive Surgery and Dermatology. Ann. Plast. Surg. 2017, 78, 736-768. [CrossRef] [PubMed] 